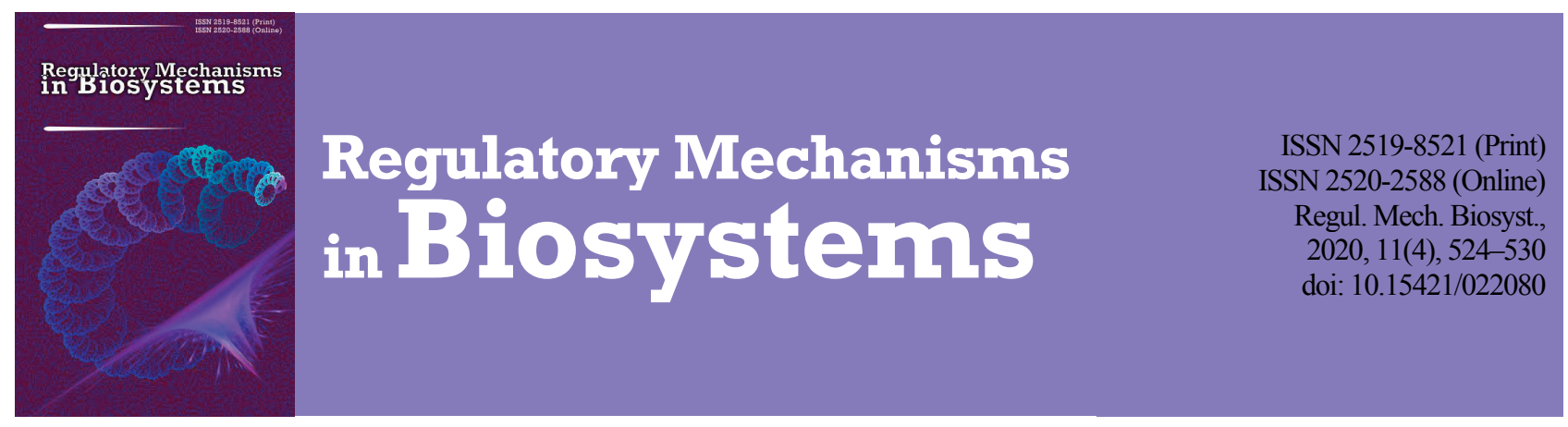

\title{
Risk factor analysis for congenital heart defects in children
}

\author{
I. V. Lastivka*, V. P. Pishak**, M. O. Ryznychuk*, T. V. Khmara* \\ *Bukovinian State Medical University, Chernivtsi, Ukraine \\ **National Academy of Pedagogical Sciences, Kyiv, Ukraine
}

Article info

Received 05.10.2020

Received in revised form 30.10 .2020

Accepted 01.11 .2020

\section{Lastivka, I. V., Pishak, V. P., Ryznychuk, M. O., Khmara, T. V. (2020). Risk factor analysis for congenital heart defects in children. Regulatory Mechanisms in Biosystems, 11(4), 524-530. doi:10.15421/022080}

Congenital heart defects (CHDs) are the most common malformations, occurring in almost 1.0 in 100 births. We investigated an association between risk factors and CHDs, because epidemiological studies have reported conflicting results regarding risk factors and CHDs recently. The study of CHD frequency was conducted in Chernivtsi region (Northern Bukovina) on the basis of the medical genetic center. A retrospective method of research by studying registration genetic maps was used to analyze risk factors. 91 cards of infants suffering from CHD (47 boys and 44 girls) aged 0-1 living in the territory of Northern Bukovina were selected. In order to identify risk factors, 133 cards of healthy infants ( 77 boys and 56 girls) were used. The analysis of risk factors revealed that the female gender of a child is a risk factor for CHD development. The analysis of the ordinal number of pregnancy revealed that the second and the third pregnancies are probable risk factors for the development of this pathology. It was found in our study that folic acid intake during the first trimester prevented CHD development (OR 2.33). The study revealed that among stressful risk factors are: unplanned pregnancy (OR 3.13); out-of-wedlock pregnancy and stress during pregnancy. Maternal CHD increased the CHD development in offspring approximately by two times. Some factors, such as a woman doing hard physical work during pregnancy, having sedentary work during pregnancy, the mother being a housewife or having an incomplete secondary education (OR 3.61), the mother's secondary education, the father's incomplete secondary education (OR 18.62), the father serving in the army (OR 2.15) or being a student at the time of woman's pregnancy (OR 2.97) were significant for CHD development in the fetal stage. A young age of the father (up to 43 years) was also considered as one of the risk factors. This article is expected to provide timely information on risk factors for CHD development to a wide range of medical staff, including pediatric and adult cardiologists, pediatricians, thoracic surgeons, obstetricians, gynecologists, medical geneticists, genetic counselors and other relevant clinicians.

Keywords: environment; heart malformations; newborns; risk factors; infants.

\section{Introduction}

Congenital heart defects, also known as congenital heart disease (CHD) are among the most common serious congenital anomalies, accounting for about a third of all defects in development and are a common cause of miscarriage, stillbirth, neonatal and infant mortality, and a major cause of many medical abortions (Chen et al., 2014; Tanner et al., 2015; Kim et al., 2017). CHDs are among the most frequent malformations among all congenital anomalies, representing one of the most widespread global healthcare problems. Heart defects compose nearly thirty percent of all major congenital anomalies (Dolk et al., 2011). The global prevalence of CHD is between eight and ten cases per 1,000 live births (Saxena, 2005), but it varies considerably between countries. The prevalence of CHD in India is reported to be between 2.5-5.0 cases per 1,000 live births, but recent studies by Bhat et al. (2013) and Smitha et al. (2006) showed a prevalence of 8.5-13.6 cases.

The frequency of $\mathrm{CHD}$ at birth (sometimes called prevalence) depends on how the population is studied. Prior to the introduction of echocardiography the incidence rates ranged 5.0-8.0 per 1,000 live births, but a more accurate diagnosis revealed many more $\mathrm{CHD}$ cases, so current rates range $8.0-12.0$ per 1,000 live births. Much depends on how early the diagnosis is made (Wren et al., 2012).

A heart ultrasound in all newborns shows that about 5\% have minor defects in the muscular part of the interventricular septum, most of which close spontaneously within a year. Minor defects of the atrial septum, which also close spontaneously, make up an even more significant percentage. In some newborns, the arterial duct closes late. Therefore, it is better to consider only those heart defects that require treatment in childhood or are present in one-year-old infants. A more accurate indicator of CHD prevalence in newborns is about $10-12$ per 1,000 live births. This number includes children with minor $\mathrm{CHD}$, which close on their own within a year and patients with non-stenotic bicuspid aortic valves. They rarely cause problems in childhood, but in adulthood lead to the development of late arterial stenosis or regurgitation (Julien-Hoffman, 2013).

Approximately $30 \%$ of infants who die at birth show signs of CHD (Rosamond et al., 2007), and in some studies they are present in approximately $1.0 \%$ of live births (Bernier et al., 2010). A study in the UK found that of 700,000 live births, $6.4 \%$ had $\mathrm{CHD}, 15 \%$ of which were lifethreatening; only $70 \%$ of them were diagnosed before birth and after birth before discharge from the hospital, and 30\% were found later with the onset of symptoms or after the death of the child (Wren et al., 2008).

While about $30 \%$ of all CHDs may be attributed to chromosomal or monogenic disorders or be influenced by other known factors, the cause of the remaining 70\% remains unknown (Jenkins et al., 2007).

Therefore, it is important to study possible etiological factors, especially where they can be changed; this can be a key step in implementing primary prevention. Over the last decade, a large number of epidemiological studies has shown that many environmental risk factors have significantly contributed to CHD development. For example, maternal alcohol consumption, smoking, medication intake and exposure to certain physical factors during pregnancy have been associated with an increased risk of developing CHD (Malik et al., 2008; Ou et al., 2016). On the other hand, taking folic acid can reduce the risk of developing these defects (Donofrio et al., 2014). 
Over the last decade, there has been a deeper understanding of the hereditary causes of congenital heart defects, including detection of specific genetic inadequacies for certain types of defects (Jenkins et al., 2007). In addition, an analysis of literary sources has shown that a large number of non-hereditary risk factors were associated with a high risk of $\mathrm{CHD}$ development, including acute and chronic maternal diseases, influence of medications, environment and parental factors. Some known risk factors included the mother suffering from rubella; phenylketonuria; gestational diabetes; taking thalidomide, large doses of vitamin A or retinoids (Donofrio et al., 2014).

Numerous studies have examined the relationship between various maternal diseases, such as hypertension, diabetes, thyroid disease, and chronic upper respiratory tract infections during pregnancy with $\mathrm{CHD}$ (Van der Lugt et al., 2012; Liu et al., 2013). There was evidence that maternal infection during pregnancy might be associated with miscarriage, stillbirth and birth defects in future generations (Kourtis et al., 2014; Wheeler et al., 2015).

As well as the most common diseases during pregnancy, the impact of colds and the mental state of pregnant women also deserve attention. The prevalence of antenatal depression or anxiety during pregnancy was noted to range 7.0-11.0 per 100 pregnant women in high-income countries (Gaynes et al., 2005; Steel et al., 2014) and 11.0-27.0 per 100 pregnant women in China (Liang et al., 2009). Psychosocial stress during pregnancy was considered a possible risk factor for chronic diseases in children (Tegethoff et al., 2008; Cookson et al., 2009).

However, most studies reported only acute infectious diseases and fever, not a specific disease, when analyzing the relationship between common diseases during pregnancy and CHD in children. It was difficult to differentiate independent and joint effects of the colds or fevers that a pregnant woman had (Ou et al., 2016). Regarding psychological factors, most studies have focused on psychological stress and anxiety (Janssen et al., 2016; Carroll et al., 2017). CHD is the leading cause of infant mortality due to congenital malformations. Several studies have shown a sharp decline in mortality and morbidity over the last century due to improvements in cardiac surgery, anesthesia and pediatric services (Moons et al., 2010; Erikssen et al., 2015). Mortality from CHD was found to have decreased significantly in the whole world between 1990 and 2017, regardless of gender, age and region of residence. However, the mortality level has varied substantially around the world, primarily due to economic development and health care (Wu et al., 2020).

The highest mortality rates from $\mathrm{CHD}$ were in low-income countries in Africa and Asia. Moreover, the tendency to increased CHD mortality occurred mainly in countries with underdeveloped economies, such as North Korea and Pakistan. On the contrary, CHD mortality in developed countries decreased significantly over the same period as reported in previous studies (Jortveit et al., 2016; Mandalenakis et al., 2016). This inequality indicates that in low-income countries, more attention should be paid to primary prevention and timely diagnosis of $\mathrm{CHD}$ to alleviate the burden of these defects. In addition, more than $80 \%$ of CHD deaths occurred in children under the age of 5 , underscoring the importance of $\mathrm{CHD}$ prevention and early CHD screening.

Although, in recent decades advances in cardiovascular medicine and surgery have dramatically reduced mortality and allowed most patients to reach adulthood, $\mathrm{CHD}$ remains the leading cause of death from congenital defects and is a heavy burden worldwide (Bouma \& Mulder, 2017; Liu et al., 2019). Thus, our objective was to study the risk factors for CHD development in children of Northern Bukovina.

\section{Materials and methods}

The study of CHD frequency was conducted in Chernivtsi region (Northern Bukovina) on the basis of the medical genetic center. Reports of the Chernivtsi Regional Diagnostic Center of the Ministry of Health of Ukraine were used, specifically form No. 49-health. "Report on the provision of medical and genetic care", approved by order No. 141 of the Ministry of Health of Ukraine dated 16.06.1993 (2007-2016). Also data contained in the statistical yearbooks of Chernivtsi region (2000-2019) concerning the number and morbidity of children in the region were analyzed. To analyze risk factors for $\mathrm{CHD}$ development we used a retrospec- tive method of research by studying registration genetic maps between 2000 and 2019, which were approved by order of the Ministry of Health of Ukraine dated 13.12.1999. 91 cards of children suffering from CHD ( 47 boys and 44 girls) aged $0-1$ living in the territory of Northern Bukovina were selected. In order to identify risk factors, 133 cards of healthy infants ( 77 boys and 56 girls) were used. The control group was formed on a population basis, as only those children whose parents lived permanently in Northern Bukovina were subject to registration.

The following data were collected from the parents: age (number of years) at the time of pregnancy, social status, the parents' bad habits, level of education of both mother and father, place of residence and place of work; somatic morbidity, ordinal number of pregnancy, placental insufficiency, threats of miscarriage, polyhydramnios or oligohydramnios, nuchal cord occurrence; a woman's gynecological health, history of abortion and miscarriages in the anamnesis; planned or unplanned pregnancies; folic acid intake in the first trimester of pregnancy, presence of stress; presence of TORCH infection during pregnancy; taking contraceptives and other medications.

The frequency of CHD cases was calculated as the ratio of CHD cases registered by the medical and genetic service during this period of time to the number of births and multiplied by 1000 . The strength of association of the analyzed signs was determined using the value of the odds ratio (OR), which was carried out according to the standart formula.

A confidence interval $(\mathrm{Cl})$ was calculated for OR at $95 \%$ significance level. If the odds ratio was less than 1 , then the risk decreased, if $=1$, then there was no risk, if more than 1, then the risk was present (Fletcher et al., 1998). All data were analyzed by nonparametric methods of variational statistics using a computer program MedCalc (2006).

\section{Results}

The analysis was conducted concerning CHD prevalence in Northern Bukovina for two periods: between 2000 and 2019 (Table 1). The frequency dynamics of CHD in newborns between 2000 and 2009 was viewed as a sinusoid with the highest rate in 2008 (7.72\%), which exceeded the average by two times. The lowest rate in the first observation period was in 2000, which may be due to improved prenatal diagnosis. In the next observation period between 2010 and 2019 the maximum number of CHDs occurred in 2019, which exceeded the average by 1.5 times, and the minimum in 2017.

Table 1

CHD prevalence (per 1000 newborns, \%) of Bukovina 2000-2019

\begin{tabular}{cccc}
\hline Year & CHD prevalence & Year & CHD prevalence \\
\hline 2000 & 0.78 & 2010 & 5.42 \\
2001 & 1.56 & 2011 & 5.71 \\
2002 & 3.72 & 2012 & 4.63 \\
2003 & 2.43 & 2013 & 5.82 \\
2004 & 3.21 & 2014 & 5.40 \\
2005 & 3.42 & 2015 & 4.92 \\
2006 & 4.14 & 2016 & 4.00 \\
2007 & 4.31 & 2017 & 1.91 \\
2008 & 7.72 & 2018 & 4.84 \\
2009 & 5.63 & 2019 & 8.32 \\
\hline
\end{tabular}

Risk factors in children with congenital heart defects were analyzed. The most important risk factors for CHD development are presented in Table 2. The analysis of risk factors revealed that female gender of the child is a risk factor for CHD development (OR 1.29). The analysis of the ordinal number of pregnancy revealed that the second (OR 1.59) and the third (OR 1.74) pregnancies are probable risk factors for the development of this pathology. Previous miscarriages, unplanned pregnancies in the anamnesis and out-of-wedlock pregnancies are also risk factors for $\mathrm{CHD}$ development.

\section{Discussion}

Our study found that in maternal age groups from 26 to 35 years and under 18 years, the risk of CHD development in their children was higher than in the group aged over 35 years. In the maternal age group from 26 to 35 years the probability of CHD presence was 1.44 (95\% CI $0.59-3.532 .5$ 
while in the group under 18 years the probability of CHD presence was 1.46 (95\% CI 0.09-23.57). These data are slightly different from the general population. Thus, a study conducted by Miller et al. showed that mothers aged over 35 years were associated with an increased risk of CHD (2011).

\section{Table 2}

The most important risk factors for congenital heart disease in children of Northern Bukovina

\begin{tabular}{|c|c|c|c|}
\hline Risk factor & $\begin{array}{c}\text { Odds } \\
\text { ratio }\end{array}$ & $\begin{array}{c}\text { Confidence } \\
\text { interval }\end{array}$ & $\begin{array}{l}\text { Probability } \\
\text { of differ- } \\
\text { ence }\end{array}$ \\
\hline Female gender of a child & 1.29 & $0.75-2.20$ & - \\
\hline Born in winter & 0.90 & $0.52-1.57$ & - \\
\hline Bom in spring & 0.99 & $0.50-1.97$ & - \\
\hline Born in summer & 1.17 & $0.58-2.12$ & - \\
\hline Born in autumn & 1.09 & $0.58-2.05$ & - \\
\hline Parents living in the countryside & 1.01 & $0.58-1.76$ & - \\
\hline \multicolumn{4}{|l|}{ Number of pregnancies: } \\
\hline Ipregnancy & 1.06 & $0.55-2.06$ & - \\
\hline II pregnancy & 1.59 & $0.77-3.28$ & - \\
\hline III pregnancy & 1.74 & $0.94-3.22$ & - \\
\hline Previous abortions & 0.37 & $0.12-1.18$ & - \\
\hline Miscarriages & 1.53 & $0.65-3.67$ & - \\
\hline Unplanned pregnancy & 3.13 & $1.79-5.48$ & $<0.001$ \\
\hline Out-of-wedlock pregnancy & 1.48 & $0.29-7.49$ & - \\
\hline Intake of folic acid in the first trimester & 2.33 & $1.31-4.13$ & $<0.05$ \\
\hline Medication intake during pregnancy & 1.54 & $0.68-3.49$ & - \\
\hline Stress during pregnancy & 3.61 & $1.21-10.78$ & $<0.05$ \\
\hline Mother suffering from anemia during pregnancy & 0.76 & $0.45-1.30$ & - \\
\hline Threat of miscarriage & 0.38 & $0.21-1.69$ & $<0.05$ \\
\hline Gestosis in the first half of pregnancy & 0.90 & $0.49-1.63$ & - \\
\hline Gestosis in the second half of pregnancy & 2.17 & $1.10-4.29$ & $<0.05$ \\
\hline Presence of TORCH infections in pregnant women & 0.69 & $0.31-1.56$ & - \\
\hline Chronic fetoplacental insufficiency & 1.13 & $0.41-3.15$ & - \\
\hline Polyhydramnios & 1.16 & $0.45-2.99$ & - \\
\hline Oligohydramnios & 3.38 & $1.09-10.5$ & $<0.05$ \\
\hline \multicolumn{4}{|l|}{ Social factors: } \\
\hline Couple living with their parents & 1.75 & $1.01-3.01$ & $<0.05$ \\
\hline Insufficient family income & 1.45 & $0.82-2.56$ & - \\
\hline Family living near highways & 1.70 & $0.95-3.05$ & - \\
\hline $\begin{array}{l}\text { Age difference of the couple is more than } \\
10 \text { years }\end{array}$ & 0.84 & $0.32-2.21$ & - \\
\hline \multicolumn{4}{|l|}{ Mother's age at the time of pregnancy: } \\
\hline Under 18 years old & 1.46 & $0.09-23.57$ & - \\
\hline Between 26 and 35 years & 1.44 & $0.59-3.53$ & - \\
\hline Over 35 years & 0.64 & $0.25-1.65$ & - \\
\hline \multicolumn{4}{|l|}{ Mother's education: } \\
\hline Secondary education & 2.37 & $1.33-4.21$ & $<0.001$ \\
\hline Incomplete secondary education & 3.61 & $0.91-14.35$ & - \\
\hline Secondary special education & 0.91 & $0.51-1.63$ & - \\
\hline Higher education & 0.34 & $0.18-0.63$ & - \\
\hline Influence of physical factors during pregnancy & 0.72 & $0.37-1.37$ & - \\
\hline Mother's social status as a worker & 1.21 & $0.66-2.21$ & - \\
\hline Hard physical work of mother during pregnancy & 2.82 & $1.29-6.11$ & $<0.001$ \\
\hline Sedentary work of mother during pregnancy & 2.26 & $0.62-8.24$ & - \\
\hline $\begin{array}{l}\text { Constant psycho-emotional stress at mother's work } \\
\text { during pregnancy }\end{array}$ & 1.13 & $0.55-2.30$ & - \\
\hline Mother being an official employee & 0.64 & $0.35-1.16$ & - \\
\hline Mother being a student & 0.70 & $0.31-1.57$ & - \\
\hline Mother being a housewife & 1.63 & $0.89-3.01$ & - \\
\hline Influence of chemical factors during pregnancy & 1.92 & $0.11-3.33$ & $<0.05$ \\
\hline Influence of biological factors during pregnancy & 0.96 & $0.56-1.66$ & - \\
\hline Mother smoking before pregnancy & 1.42 & $0.63-3.18$ & - \\
\hline Mother smoking during pregnancy & 0.69 & $0.30-1.58$ & - \\
\hline Mother abusing coffee during pregnancy & 0.62 & $0.32-1.19$ & - \\
\hline Mother abusing alcohol during pregnancy & 1.07 & $0.29-3.94$ & - \\
\hline $\begin{array}{l}\text { Mother having chronic diseases of the } \\
\text { cardiovascular system }\end{array}$ & 0.48 & $0.19-1.20$ & - \\
\hline $\begin{array}{l}\text { Mother having chronic diseases of the } \\
\text { gastrointestinal tract }\end{array}$ & 0.23 & $0.03-1.87$ & - \\
\hline Mother having thyroid diseases & 0.20 & $0.08-0.52$ & $<0.001$ \\
\hline Mother suffering from other chronic diseases & 2.67 & $1.07-6.67$ & $<0.05$ \\
\hline $\begin{array}{l}\text { Mother came down with SARS in the first trimester } \\
\text { of pregnancy }\end{array}$ & 0.72 & $3.13-24.31$ & $<0.001$ \\
\hline Treatment of maternal infertility & 0.83 & $0.24-2.91$ & - \\
\hline Mother having CHD & 2.25 & $0.20-25.21$ & - \\
\hline
\end{tabular}

\begin{tabular}{|c|c|c|c|}
\hline Risk factor & $\begin{array}{l}\text { Odds } \\
\text { ratio }\end{array}$ & $\begin{array}{c}\text { Confidence } \\
\text { interval }\end{array}$ & $\begin{array}{c}\begin{array}{c}\text { Probability } \\
\text { of differ- } \\
\text { ence } \\
\end{array} \\
\end{array}$ \\
\hline $\begin{array}{l}\text { Father's age at the time of conception is under } \\
43 \text { years }\end{array}$ & 3.28 & $1.19-9.06$ & $<0.05$ \\
\hline $\begin{array}{l}\text { Father's age at the time of conception is over } \\
43 \text { years }\end{array}$ & 0.30 & $0.11-0.84$ & $<0.05$ \\
\hline Father's education & & & - \\
\hline Secondary education & 1.28 & $0.74-2.22$ & - \\
\hline Incomplete secondary education & 18.62 & $2.36-146.9 t$ & $<0.05$ \\
\hline Secondary special education & 1.11 & $0.61-1.99$ & - \\
\hline Higher education & 0.35 & $0.18-0.67$ & $<0.05$ \\
\hline Father's social status as a worker & 2.21 & $1.23-3.99$ & $<0.05$ \\
\hline Father's social status as an official employee & 0.60 & $0.28-1.25$ & - \\
\hline Father's social status as a peasant & 0.72 & $0.13-4.04$ & - \\
\hline Father's social status as an entrepreneur & 0.09 & $0.01-0.73$ & $<0.05$ \\
\hline $\begin{array}{l}\text { Father serving in the army at the time of woman's } \\
\text { pregnancy }\end{array}$ & 2.15 & $1.19-3.87$ & $<0.05$ \\
\hline $\begin{array}{l}\text { Father being a student at the time of woman's } \\
\text { pregnancy }\end{array}$ & 2.97 & $0.27-33.21$ & - \\
\hline Father being a member of the military personnel & 1.11 & $0.24-5.09$ & - \\
\hline Constant psycho-emotional stress at father's work & 0.69 & $0.36-1.33$ & - \\
\hline Hard physical work of the father before conception & 2.27 & $1.31-3.96$ & $<0.05$ \\
\hline $\begin{array}{l}\text { Influence of physical factors on father before } \\
\text { pregnancy }\end{array}$ & 1.24 & $0.62-2.45$ & - \\
\hline $\begin{array}{l}\text { Influence of chemical factors on father before } \\
\text { pregnancy }\end{array}$ & 1.41 & $0.81-2.45$ & - \\
\hline $\begin{array}{l}\text { Influence of biological factors on father before } \\
\text { pregnancy }\end{array}$ & 0.66 & $0.29-1.47$ & - \\
\hline Father being a smoker & 1.58 & 69 & - \\
\hline Father abusing coffee & 0.58 & $0.33-1.02$ & - \\
\hline Father abusing alcohol & 0.66 & $0.37-1.17$ & - \\
\hline Father suffering from chronic diseases & 2.40 & $1.22-4.72$ & $<0.05$ \\
\hline $\begin{array}{l}\text { Father having chronic diseases of the cardiovascular } \\
\text { system }\end{array}$ & 36.13 & $4.06-321.1$ & $<0.001$ \\
\hline $\begin{array}{l}\text { Father having chronic diseases of the gastrointestinal } \\
\text { tract }\end{array}$ & 0.68 & $0.12-3.84$ & - \\
\hline Father having thyroid diseases & 0.15 & $0.01-1.44$ & - \\
\hline Father suffering from other chronic & 1.45 & $0.42-4.96$ & - \\
\hline Father having CHD & 0.25 & $0.06-1.03$ & - \\
\hline Father having $\mathrm{Rh}+$ & 3.28 & $1.51-7.40$ & $<0.001$ \\
\hline $\begin{array}{l}\text { Diseases of the cardiovascular system in the fourth } \\
\text { generation on the mother's side }\end{array}$ & 0.44 & $0.21-0.93$ & $<0.05$ \\
\hline Cancer in the fourth generation on the mother's side & 1.16 & $0.55-2.42$ & - \\
\hline Diabetes in the fourth generation on the mother's side & 10.19 & $4.03-25.75$ & $<0.001$ \\
\hline $\begin{array}{l}\text { Diseases of the cardiovascular system in the third } \\
\text { generation on the mother's side }\end{array}$ & 2.93 & $28-6.67$ & $<0.05$ \\
\hline Cancer in the third generation on the mother's side & 5.11 & $1.91-13.66$ & $<0.001$ \\
\hline Diabetes in the third generation on the mother's side & 0.79 & $0.22-2.82$ & - \\
\hline CHD in the third generation on the mother's side & 12.53 & $0.58-267.1$ & - \\
\hline $\begin{array}{l}\text { Thyroid diseases in the third generation on the } \\
\text { mother's side }\end{array}$ & 1.06 & $0.15-7.66$ & - \\
\hline Cancer in the fourth generation on the father's side & 0.69 & $0.30-1.58$ & - \\
\hline $\begin{array}{l}\text { Diseases of the cardiovascular system in the fourth } \\
\text { generation on the father's side }\end{array}$ & 1.96 & $0.86-4.46$ & - \\
\hline $\begin{array}{l}\text { Diseases of the cardiovascular system in the third } \\
\text { generation on the father's side }\end{array}$ & 1.22 & $0.48-3.09$ & - \\
\hline Diabetes in the third generation on the father's side & 0.30 & $0.05-1.68$ & - \\
\hline CHD on the father's side & 4.47 & $0.21-96.41$ & - \\
\hline Cancer in the third generation on the father's side & 0.81 & $0.26-2.45$ & - \\
\hline & 3.94 & $0.21-75.29$ & - \\
\hline Thyroid diseases on the mother's side & 2.27 & $0.85-6.07$ & - \\
\hline Thyroid diseases on the father's side & 13.58 & $3.91-47.8$ & $<0.001$ \\
\hline
\end{tabular}

A meta-analysis by Hackshaw et al. (2011) assessed the effect of the mother's smoking on the spectrum of congenital defects, including heart defects (OR 1.09; 95\% CI 1.02-1.17). A meta-analysis of studies published between 1971 and 2011 (23 case-control studies, 5 cohort studies, and 5 cross-sectional studies) found a positive correlation for all combined CHDs (OR 1.11; 95\% CI 1.02-1.21). Our study found an effect of maternal smoking before pregnancy (OR 1.42; 95\% CI 0.63 - 3.38) (Lee \& Lupo, 2013).

The Baltimore-Washington Infant Study concluded that the mother smoking more than one pack of cigarettes a day led to certain CHDs: ventricular septal defect and pulmonary artery stenosis (women over 34 years) (Correa-Villaseñor et al., 1993). The study by Polifka \& Fried- 
man (2002) reported a link between maternal cigarette smoking and specific CHD (ventricular septal defect, tetralogy of Fallot).

The Nicoll study as well as later studies that showed a link between CHD and maternal smoking did not show a high OR for all CHDs; in fact, higher OR rates were found for parental or passive smoking (2018). A study conducted in the United States showed that the effects on the mother caused by secondhand smoking at home and at work led to the development of atrial septal defects with OR 1.37 (95\% CI $1.09-1.72)$ (Hoyt et al., 2016), while maternal and paternal smoking resulted in an additive effect with OR 4.5 (95\% CI 2.5-8.3) (Cresci et al., 2011). Parental smoking of more than 14 cigarettes a day more than doubled the risk of CHD (OR 2.1 95\% CI 1.3-3.5) (Baardman et al., 2012). This and other studies cannot explain why the risk of CHD increases with secondhand or parental smoking. These data may indicate that mothers often conceal the fact of smoking. A hospital case-control study of nicotine levels in the hair revealed a dose-response effect with OR rising for all CHDs due to increase of nicotine levels in the hair (Li et al., 2015).

The study revealed that the intake of folic acid during the first trimester prevented CHD development (OR 2.33; 95\% CI 1.31-4.13, $\mathrm{P}<0.05$ ). A Hungarian randomized trial (Botto et al., 2000) and the Atlanta casecontrol study showed a similar correlation in which CHD risk in offspring was reduced by $60 \%$ and $25 \%$ for mothers who took folic acid in the first trimester of pregnancy (Scanlon et al., 1998). The analysis of pregnant women who had SARS during the first trimester found that this indicator was not a risk factor for CHD development (OR $0.72,95 \%$ CI 3.13 24.31, P < 0.001). However, the study of Shi et al. (2014) showed that mothers who had a history of SARS in the first trimester had an increased chance of CHD developing in their children (OR 3.717; 95\% CI 1.638.50) (Abquari et al., 2016). Our study demonstrated that CHD probability in children was increased with mothers who had a history of previous miscarriages (OR 1.53, 95\% CI 0.65-3.67), gestosis in the second half of pregnancy (OR 2.17, 95\% CI 1.10-4.29, P $<0.05$ ), chronic fetoplacental insufficiency (OR 1.13, 95\% CI 0.41-3.15), polyhydramnios (OR 1.16, 95\% CI 0.45-2.99) and dehydration (OR 3.38, 95\% CI 1.09-10.5, P < $0.05)$. Thus, regular fetal screening is strongly recommended, especially in high-risk pregnancies. However, some researchers Hasan et al. (1997) did not find such a correlation.

Maternal stress can often be a risk factor for developmental anomalies, including CHD. The study found that among stressful risk factors were: unplanned pregnancy (OR 3.13, 95\% CI 1.79-5.48, P <0.001); outof-wedlock pregnancy (OR 1.48, 95\% CI 0.28-7.49); stress during pregnancy (OR 3.61, 95\% CI 1.21-10.78, P < 0.05). In a study by Liu et al. (2009) maternal stress during the first trimester of pregnancy was a significant risk factor for CHD development (OR 3.93; 95\% CI, 1.94-7.94). However, some researchers did not find a connection between stress during pregnancy and CHD development (Mateja et al., 2012).

Some social factors, such as: couples living with parents (OR 1.75, 95\% CI 1.01-3.01, P < 0.05); insufficient family income (OR 1.45, 95\% CI 0.82-2.56); families living near highways (OR 1.70, 95\% CI 0.95 3.05) are also considered as risk factors in CHD development.

In a study by Chou et al. (2016) maternal congenital heart defects increased risk of CHD development in offspring by about three times, which is consistent with other studies (Liu et al., 2013) as well as with our data (OR 2.25, 95\% CI 0.20-25.21). Apparently genetic predisposition plays an important role.

Taking medication during pregnancy, especially in the first trimester increased the risk of CHD in offspring by 1.5 times (OR $1.54,95 \% \mathrm{CI}$ 0.68-3.49). A study by Li et al. (2018) found that women of childbearing age who had taken cold medications, antibiotics, drugs containing salicylic acid, antifungals, and other drugs during early stages of pregnancy increased the risk of their children developing CHD.

A study Rappazzo et al. (2016) examined the effects of particular chemicals on pregnant women and found an increased risk of developing certain CHDs, the same data were found in a study by Carmichael (2014). Our study showed that the influence of chemical factors during pregnancy on CHD development was significant (OR 1.92, 95\% CI $0.11-3.33, \mathrm{P}<0.05)$.

Some particular factors, such as hard physical work of the mother during pregnancy (OR 2.82, 95\% CI 0.62-8.24, $\mathrm{P}<0.001$ ), sedentary work of a pregnant woman (OR 2.26, 95\% CI $0.62-8.24, \mathrm{P}<0.05)$, the mother being a housewife (OR 1.63, 95\% CI 0.89-3.01), the mother's incomplete secondary education (OR 3.61, 95\% CI 0.91-14.35), the mother's secondary education (OR 2.37, 95\% CI 1.33-4.21, P <0.001), the father's incomplete secondary education (OR 18.62, 95\% CI 2.36146.96), the father serving in the army at the time of his partner's pregnancy (OR 2.15, 95\% CI 1.19-3.87, P < 0.05) or the father being a student at the time of his partner's pregnancy (OR 2.97, 95\% CI 0.27-33.21) are significant in CHD development in a fetal stage.

There is a high risk of CHD associated with a low level of maternal education, which persisted after adjusting for other risk factors, suggesting that certain environmental factors associated with maternal education (possibly due to individual socioeconomic status) are relevant and require further research. Studies in the United Kingdom (Vrijheid et al., 2000) and Canada (Agha et al., 2011) found a higher risk of ATC associated with parents' low socioeconomic levels.

The study by Su et al. (2015) did not find a general connection between the father's age and the prevalence of combined CHD in offspring. The young age of the father (under 43 years) was a risk factor in our study (OR 3.28, CI 1.19-9.06, $\mathrm{P}<0.05$ ). A real explanation for the effect of young age is that unhealthy lifestyles and the presence of bad habits such as smoking and alcohol consumption may predominate among young couples (Kazaura et al., 2004).

Mother's usage of alcohol during pregnancy is associated with the development of congenital defects in children (Polifka \& Friedman, 2002; Brent, 2004). Adverse effects of alcohol on the fetus include a range of structural anomalies and behavioural disorders (Autti-Ramo et al., 2006) and lead to an increase in the number of newborns with fetal alcohol syndrome (Shillingford \& Weiner, 2001). Shillingford \& Weiner (2001) reported that atrial septal defects were the most common heart defects these newborns had.

The study by Martinez-Frias et al. (2004) conducted in Spain found that the highest risk of developing $\mathrm{CHD}$ was in the group with the highest prenatal alcohol exposure (absolute alcohol intake was over $92 \mathrm{~g}$ per day). Cigarette smoking is a well-known teratogenic risk factor for congenital defects and can affect the development of certain organ systems (Lee et al., 2013). Nicotine can strongly affect sperm activity and cause chromosomal aberration, which can affect fetal development and lead to heart defects (Correa et al., 2015). In addition, parental smoking can cause passive smoking by the mother, which can also increase the risk of CHD development (Liu et al., 2017). Our study showed the father's smoking as a risk factor for developing CHD (OR 1.58, CI 0.92-2.69).

Risk factors for CHD development from the father's side were: social status of the father as a worker (OR 2.21, CI 1.23-3.99, P <0.05); hard physical work of the father before conception (OR 2,27, CI 1.31-3.96, P < $0,05)$; influence of chemical factors on the father before conception (OR 1.41, CI 0.81-2.45). Studies that evaluated the effects of chemical agents or drugs on the father of a child with CHD were analyzed. The effect of chemicals or drugs on parents was found to be closely associated with an increased risk of CHD (OR 2.15, CI 1.53-3.02) (Fleming et al., 2014). Certain occupations of fathers, such as factory workers, janitors, painters and plywood factory workers may increase the risk of development of CHD (Fleming et al., 2014; Rufer et al., 2010). However, conflicting results have been shown in studies on the connection between the father being a firefighter and CHD risk in the offspring (Selevan et al., 2000).

In addition to the abovementioned risk factors, there are also several studies on other factors from the father's side, such as chronic diseases, viral infections etc., which revealed that the father having a viral infection (OR 2.46, 95\% CI 1.13-5.35) or taking antibiotics (OR 10.04, 95\% CI 1.28-78.45) might also increase CHD risk (Nie et al., 2013; Li et al., 2017). The presence of chronic diseases in the father (OR 2.40, 95\% CI 1.22-4.72), especially chronic diseases of the cardiovascular system (OR $30.13,95 \%$ CI $4.06-321.10$ ) is shown to be among risk factors for CHD development. The following factors in parents are largely associated with an increased risk of CHD: family history of CHD (OR 5.23), the mother having chronic diseases (OR 4.19), environmental pollution at the mother's place of residence $(\mathrm{OR}=3.63)$, chronic disease of the father $(\mathrm{OR}$ 4.87) (Jiayu Peng et al., 2019). Our study also identified certain risk factors that provoked CHD development, i.e. the mother suffering from other 
chronic diseases (OR 2.67, 95\% CI 1.07-6.67, $\mathrm{P}<0.05)$. The pedigree analysis identified $\mathrm{CHD}$ risk factors associated with previous generations having the following diseases: diabetes in the fourth generation on the mother's side (OR 10.19, 95\% CI 4.03-25.75, $\mathrm{P}<0.001$ ), diseases of the cardiovascular system in the third (OR 2.93, 95\% CI 1.28-6.67, P < 0.05) and the fourth generations (OR $1.96,95 \%$ CI $0.86-4.46$ ) on the mother's side, cancer in the third generation on the mother's side (OR 5.11, 95\% CI 1.91-13.66), diseases of the cardiovascular system in the third generation on the father's side (OR 1.22, 95\% CI 0.48-3.09), congenital heart defects on the father's side (OR 4,47, 95\% CI 0,21-96.41), congenital heart defects from previous pregnancies (OR 3.94, 95\% CI 0.21-75.29), thyroid diseases on the mother's side (OR 2.27, 95\% CI 0.85-6.07) and on the father's side (OR 13.58, 95\% CI 3.91-47.8).

The mother's having pregestational diabetes increases the risk of CHD. Maternal diabetes is usually associated with a wide range of CHDs: transposition of the great vessels, non-chromosomal atrioventricular septal defects, double outlet right ventricle, tetralogy of Fallot, hypoplastic left heart syndrome and cardiomyopathy. Recent studies have shown that long-term maternal diabetes increased the risk of congenital cardiovascular disorders (Nielsen et al., 2005).

The teratogenic mechanism of maternal diabetes has not been fully studied and is probably multifactorial (Hornberger, 2006; Nold \& Georgieff, 2004). It is possible that presence of increased osmolarity and abnormal levels of ketones, imbalance of amino acids and fatty acids may contribute to CHD development. High glucose levels in the blood can cause congenital malformations, inhibiting glycolysis, i.e. the main process of energy production during embryogenesis (Nold \& Georgieff, 2004). Hyperglycemia has a direct effect on the proliferation and migration of neural crest cells, which are important for heart development. A recent study by Roest et al. (2007) showed a high incidence of cardiovascular malformations in embryos whose cardiac neural crest cells experienced elevated glucose levels. Another study reported that abnormal glucose levels in embryos disrupted the expression of Pax-3, a developmental control gene that is an important factor in the transcription of cardiac neural crest cells (Epstein et al., 2000).

The effects of preconception diabetes begin during embryonic development in the first trimester; and continues to affect the fetus in the second and third trimesters and the newborn in the perinatal and neonatal periods (Hornberger, 2006).

The risk of developing CHD can be significantly reduced due to a good control of blood glucose levels. On the contrary, the mother having a long-term type 1 diabetes as well as poor glycemic control before and during pregnancy increase the risk of congenital malformations (Kalaidzhieva et al., 2003).

\section{Conclusions}

The risk factors for CHD development in offspring may vary, namely the mother having chronic diseases, CHDs, chronic stress, the mother's age (under 18 years and between 26 and 35 years), social status (incomplete secondary and secondary education), exposure to chemical factors, medication intake during pregnancy, smoking before and during the pregnancy, complicated pregnancy (dehydration, previous miscarriages, gestosis during the second half of pregnancy) or the family living near highways.

The analysis of non-genetic risk factors for CHD development on the father's side revealed the high impact of incomplete secondary education, place of work before pregnancy (worker, serving in the military, the father being a student), the habit of smoking, hard physical work, influence of chemical factors before conception, the father suffering from chronic diseases, especially of the cardiovascular system. Also, such risk factors as pedigree analysis showing presence of diseases of the cardiovascular system, thyroid diseases both on the mother's and father's sides, cancer on the mother's side and congenital heart defects from previous pregnancies should be taken into account.

The results of this study can be used in family counseling before conception and in identifying high-risk pregnant women. Women with relevant risk factors should eliminate them as much as possible before conception to minimize the risk of congenital heart defects in their children.
It is important to encourage fertility at a certain age, to form healthy lifestyle habits, starting with quitting smoking and drinking and trying to avoid exposure to chemical and environmental factors.

Prenatal screening is recommended for high-risk pregnant women, if necessary, using invasive methods. Early detection of congenital heart defects also allows medical staff to optimally prepare and provide care during pregnancy, childbirth and puerperium.

\section{References}

Abqari, S., Gupta, A., Shahab, T., Rabbani, M. U., Ali, S. M., \& Firdaus, U. (2016). Profile and risk factors for congenital heart defects: A study in a tertiary care hospital. Annals of Pediatric Cardiology, 9(3), 216-221.

Agha, M. M., Glazier, R. H., Moineddin, R., Moore, A. M., \& Guttmann, A. (2011). Socioeconomic status and prevalence of congenital heart defects: Does universal access to health care system eliminate the gap? Birth defects research. Part A, Clinical and Molecular Teratology, 91(12), 1011-1018.

Autti-Ramo, I., Fagerlund, A., Ervalahti, N., Loimu, L., Korkman, M., \& Hoyme, H. E. (2006). Fetal alcohol spectrum disorders in Finland: Clinical delineation of 77 older children and adolescents. American Journal of Medical Genetics, 140(2), 137-143.

Baardman, M. E., Kerstjens-Frederikse, W. S., Corpeleijn, E., de Walle, H. E., Hofstra, R. M., Berger, R. M., \& Bakker, M. K. (2012). Combined adverse effects of maternal smoking and high body mass index on heart development in offspring: Evidence for interaction? Heart, 98(6), $474-479$.

Bernier, P. L., Stefanescu, A., Samoukovic, G., \& Tchervenkov, C. I. (2010). The challenge of congenital heart disease worldwide: Epidemiologic and demographic facts. Seminars in thoracic and cardiovascular surgery. Pediatric Cardiac Surgery Annual, 13(1), 26-34.

Bhat, N. K., Dhar, M., Kumar, R., Patel, A., Rawat, A., \& Kalra, B. P. (2013). Prevalence and pattern of congenital heart disease in Uttakhand, India. Indian Journal of Pediatrics, 80(4), 281-285.

Botto, L. D., Mulinare, J., \& Erickson, J. D. (2000). Occurrence of congenital heart defects in relation to maternal multivitamin use. American Journal of Epidemiology, 151(9), 878-884.

Bouma, B. J., \& Mulder, B. J. (2017). Changing landscape of congenital heart disease. Circulation Research, 120(6), 908-922.

Brent, L. (2004). Environmental causes of human congenitalmalformations: The pediatrician's role in dealing with these complex clinical problems caused by a multiplicity of environmental and genetic factors. Pediatrics, 113(4), 957-968.

Carmichael, S. L., Yang, W., Roberts, E., Kegley, S. E., Padula, A. M., English, P. B., Lammer, E. J., \& Shaw, G. M. (2014). Residential agricultural pesticide exposures and risk of selected congenital heart defects among offspring in the San Joaquin Valley of California. Environmental Research, 135, 133-138.

Carroll, A. J., Carnethon, M. R., Liu, K., Jacobs, D. R., Colangelo, L. A., Stewart, J. C., Carr, J. J., Widome, R., Auer, R., \& Hitsman, B. (2016). Interaction between smoking and depressive symptoms with subclinical heart disease in the Coronary Artery Risk Development in Young Adults (CARDIA) study. Health Psychology, 36(2), 101-111.

Chen, E. K., Zmirou-Navier, D., Padilla, C., \& Deguen, S. (2014). Effects of air pollution on the risk of congenital anomalies: A systematic review and meta-analysis. International Journal of Environmental Research and Public Health, 11(8), 7642-7668.

Chou, H. H., Chiou, M. J., Liang, F. W., Chen, L. H., Lu, T. H., \& Li, C. Y. (2016). Association of maternal chronic disease with risk of congenital heart disease in offspring. Canadian Medical Association Journal, 188(17-18), E438-E446.

Correa, A., Levis, D. M., Tinker, S. C., \& Cragan, J. D. (2015). Maternal cigarette smoking and congenital heart defects. The Journal of Pediatrics, 166(4), 801-804.

Correa-Villaseñor, A., Ferencz, C., Loffredo, C., \& Magee, C. (1993). Paternal exposures and cardiovascular malformations. The Baltimore-Washington Infant Study Group. Journal of Exposure Analysis and Environmental Epidemiology, 3(Suppl 1), 173-185.

Cresci, M., Foffa, I., Ait-Ali, L., Pulignani, S., Gianicolo, E. A., Botto, N., Picano, E., \& Andreassi, M. G. (2011). Maternal and paternal environmental risk factors, metabolizing GSTM1 and GSTT1 polymorphisms, and congenital heart disease. The American Journal of Cardiology, 108(11), 1625-1631.

Dolk, H., Loane, M., Garne, E., \& European Surveillance of Congenital Anomalies (EUROCAT) Working Group (2011). Congenital heart defects in Europe: Prevalence and perinatal mortality, 2000 to 2005. Circulation, 123(8), 841-849.

Donofrio, M. T., Moon-Grady, A. J., Hornberger, L. K., Copel, J. A., Sklansky, M. S., Abuhamad, A., Cuneo, B. F., Huhta, J. C., Jonas, R. A., Krishnan, A., Lacey, S., Lee, W., Michelfelder, E. C. S., Rempel, G. R., Silverman, N. H., Spray, T. L., Strasburger, J. F., Tworetzky, W., Rychik, J., American Heart Association Adults With Congenital Heart Disease Joint Committee of the Council on Cardiovascular Disease in the Young and Council on Clinical Cardiology, \& Council on Cardiovascular Surgery and Anesthesia, and Council on 
Cardiovascular and Stroke Nursing. (2014). Diagnosis and treatment of fetal cardiac disease: A scientific statement from the American Heart Association. Circulation, 129(21), 2183-2242.

Entringer, S., Wüst, S., Kumsta, R., Layes, I. M., Nelson, E. L., Hellhammer, D. H., \& Wadhwa, P. D. (2008). Prenatal psychosocial stress exposure is associated with insulin resistance in young adults. American Journal of Obstetrics and Gynecology, 199(5), 498

Epstein, J. A., Li, J., Lang, D., Chen, F., Brown, C. B., Jin, F., Lu, M. M., Thomas M., Liu, E., Wessels, A., \& Lo, C. W. (2000). Migration of cardiac neural crest cells in Splotch embryos. Development, 127(9), 1869-1878.

Erikssen, G., Liestøl, K., Seem, E., Birkeland, S., Saatvedt, K. J., Hoel, T. N., Døhlen, G., Skulstad, H., Svennevig, J. L., Thaulow, E., \& Lindberg, H. L. (2015) Achievements in congenital heart defect surgery: A prospective, 40-year study of 7038 patients. Circulation, 131(4), 337-346.

Fleming, D. A., Woskie, S. R., Jones, J. H., Silver, S. R., Luo, L., \& Bertke, S. J. (2014). Retrospective assessment of exposure to chemicals for a microelectronics and business machine manufacturing facility. Journal of Occupational and Environmental Hygiene, 11(5), 292-305.

Fletcher, R., Fletcher, S., \& Vagner, J. (1998). Klinicheskaja epidemiologija. Osnovy dokazatel'noj mediciny [Clinical epidemiology. Evidence-based medicine basics]. Media Sfera, Moscow (in Russian)

Gaynes, B. N., Gavin, N., Meltzer-Brody, S., Lohr, K. N., Swinson, T., Gartlehner, G., Brody, S., \& Miller, W. C. (2005). Perinatal depression: Prevalence, screening accuracy, and screening outcomes. Evidence Report/Technology Assessment, $119,1-8$

Hackshaw, A., Rodeck, C., \& Boniface, S. (2011). Maternal smoking in pregnancy and birth defects: A systematic review based on 173687 malformed cases and 11.7 million controls. Human Reproduction Update, 17(5), 589-604

Hasan, I., Haleem, A. A., \& Bhutta, Z. A. (1997). Profile and risk factor for congenital heart disease. Journal of the Pakistan Medical Association, 47(3), 78-81.

Hoffman, J. I. E. (2013). The global burden of congenital heart disease. Cardiovascular Journal of Africa, 24(4), 141-145.

Hornberger, L. K. (2006). Maternal diabetes and the fetal heart. Heart, 92(8), 1019 1021.

Hoyt, A. T., Canfield, M. A., Romitti, P. A., Botto, L. D., Anderka, M. T., Krikov, S. V., Tarpey, M. K., \& Feldkamp, M. L. (2016). Associations between maternal periconceptional exposure to secondhand tobacco smoke and major birth defects. American Journal of Obstetrics and Gynecology, 215, e1-e11.

Janssen, I., Powell, L. H., Matthews, K. A., Jasielec, M. S., Hollenberg, S. M., Bromberger, J. T., Sutton-Tyrrell, K., \& Everson-Rose, S. A. (2016). Relation of persistent depressive symptoms to coronary artery calcification in women aged 46 to 59 years. The American Journal of Cardiology, 117(12), 1884-1889.

Jenkins, K. J., Correa, A., Feinstein, J. A., Botto, L., Britt, A. E., Daniels, S. R., Elixson, M., Warnes, C. A., Webb, C. L., \& American Heart Association Counci on Cardiovascular Disease in the Young (2007). Noninherited risk factors and congenital cardiovascular defects: Current knowledge: A scientific statement from the American Heart Association Council on Cardiovascular Disease in the Young: Endorsed by the American Academy of Pediatrics. Circulation, 115(23), 2995-3014.

Jortveit, J., Øyen, N., Leirgul, E., Fomina, T., Tell, G. S., Vollset, S. E., Eskedal, L., Døhlen, G., Birkeland, S., \& Holmstrøm, H. (2016). Trends in mortality of congenital heart defects. Congenital Heart Disease, 11(2), 160-168.

Kalaĭdzhieva, M., Popivanova, A., Dořcheva, E., Nikolov, A., \& Dimitgrov, A (2003). Maichin diabet i vrodeni malformatsii na novorodenoto [Maternal insulin-dependent diabetes and congenital malformations in the newborn]. Akusherstvo i Ginekologiia (Sofiia), 42(3), 3-5 (in Bulgarian).

Kazaura, M., Lie, R. T., \& Skjaerven, R. (2004). Paternal age and the risk of birth defects in Norway. Annals of Epidemiology, 14(8), 566-570

Kim, J., Swartz, M. D., Langlois, P. H., Romitti, P. A., Weyer, P., Mitchell, L. E., Luben, T. J., Ramakrishnan, A., Malik, S., Lupo, P. J., Feldkamp, M. L., Meyer, R. E., Winston, J. J., Reefhuis, J., Blossom, S. J., Bell, E., Agopian, A. J., \& National Birth Defects Prevention Study (2017). Estimated maternal pesticide exposure from drinking water and heart defects in offspring. International Journal of Environmental Research and Public Health, 14(8), 889.

Kourtis, A. P., Read, J. S., \& Jamieson, D. J. (2014). Pregnancy and infection. New England Journal of Medicine, 370(23), 2211-2218.

Lee, L. J., \& Lupo, P. J. (2013). Maternal smoking during pregnancy and the risk of congenital heart defects in offspring: A systematic review and metaanalysis. Pediatric Cardiology, 34(2), 398-407.

Li, H., Luo, M., Zheng, J., Luo, J., Zeng, R., Feng, N., Du, Q., \& Fang, J. (2017). An artificial neural network prediction model of congenital heart disease based on risk factors: A hospital-based case-control study. Medicine (Baltimore), 96(6), e6090.

Li, M. M., Guo, L. Q., Li, S. S., Zhang, Q., Zhao, D. D., Zhang, B. Y., Dang, S. N., \& Yan, H. (2018). [Association between congenital heart disease and medication taken during pregnancy among women of childbearing age]. Zhonghua Liu Xing Bing Xue Za Zhi, 39(10), 1333-1338 (in Chinese).
Li, X., Liu, Z., Deng, Y., Li, S., Mu, D., Tian, X., Lin, Y., Yang, J., Li, J., Li, N. Wang, Y., Chen, X., Deng, K., \& Zhu, J. (2015). Modification of the association between maternal smoke exposure and congenital heart defects by polymorphisms in glutathione-S-transferase genes. Scientific Reports, 5, 14915.

Liang, J. J., Huang, C. X., Yang, B., Huang, H., Wan, J., Tang, Y. H., \& Zhao, Q. Y. (2009). Depressive symptoms and risk factors in Chinese patients with premature ventricular contractions without structural heart disease. Clinical Cardiology, 32(11), E11-E17.

Liu, S., Joseph, K. S., Lisonkova, S., Rouleau, J., Van den Hof, M., Sauve, R., Kramer, M. S. \& Canadian Perinatal Surveillance System (Public Health Agency of Canada) (2013). Association between maternal chronic conditions and congenital heart defects: A population-based cohort study. Circulation, 128(6), 583-589.

Liu, S., Liu, J., Tang, J., Ji, J., Chen, J., \& Liu, C. (2009). Environmental risk factors for congenital heart disease in the Shandong Peninsula, China: A hospital-based case-control study. Journal of Epidemiology, 19(3), 122-130.

Liu, Y., Chen, S., Zühlke, L., Black, G. C., Choy, M. K., Li, N., \& Keavney, B. D. (2019). Global birth prevalence of congenital heart defects 1970-2017: Updated systematic review and meta-analysis of 260 studies. International Journal of Epidemiology, 48(2), 455-463.

Liu, Y., Zhu, B., Zhuo, L., He, M. Y., Xu, Y., Wang, T. T., Cai, Q. Q., Hu, B., Xu, J. C., \& Zhang, W. H. (2017). [Risk factors for congenital heart disease in Chinese neonates: A meta analysis]. Zhongguo Dang Dai Er Ke Za Zhi, 19(7), 754-758 (in Chinese)

Malik, S., Cleves, M. A., Honein, M. A., Romitti, P. A., Botto, L. D., Yang, S, Hobbs, C. A, \& National Birth Defects Prevention Study (2008). Maternal smoking and congenital heart defects. Pediatrics, 121(4), e810-e816.

Mandalenakis, Z., Rosengren, A., Skoglund, K., Lappas, G., Eriksson, P., \& Dellborg, M. (2016). Survivorship in children and young adults with congenital heart disease in Sweden. JAMA Internal Medicine, 177(2), 224-230.

Martínez-Frías, M. L., Bermejo, E., Rodríguez-Pinilla, E., \& Frías, J. L. (2004). Risk for congenital anomalies associated with different sporadic and daily doses of alcohol consumption during pregnancy: A case-control study. Birth Defects Research. Part A, Clinical and Molecular Teratology, 70(4), 194-200.

Mateja, W. A., Nelson, D. B., Kroelinger, C. D., Ruzek, S., \& Segal, J. (2012). The association between maternal alcohol use and smoking in early pregnancy and congenital cardiac defects. Journal of Women's Health, 21(1), 26-34.

Miller, A., Riehle-Colarusso, T., Siffel, C., Frías, J. L., \& Correa, A. (2011). Maternal age and prevalence of isolated congenital heart defects in an urban area of the United States. American Journal of Medical Genetics. Part A, 155A(9), 21372145

Moons, P., Bovijn, L., Budts, W., Belmans, A., \& Gewillig, M. (2010). Tempora trends in survival to adulthood among patients bom with congenital heart disease from 1970 to 1992 in Belgium. Circulation, 122(22), 2264-2272

Nicoll, R. (2018). Environmental contaminants and congenital heart defects: A reevaluation of the evidence. International Journal of Environmental Research and Public Health, 15(10), 2096.

Nie, Z. Q., Ou, Y. Q., Chen, J. M., Liu, X. Q., Mai, J. Z., Gao, X. M., Wu, Y., \& Zhuang, J. (2013). [Risk factors of congenital heart defects in fetal and infants born from 2004 to 2011 in Guangdong]. Zhonghua Xin Xue Guan Bing Za Zhi, 41(8), 704-708 (in Chinese).

Nielsen, G. L., Nørgard, B., Puho, E., Rothman, K. J., Sørensen, H. T., \& Czeizel, A. E. (2005). Risk of specific congenital abnormalities in offspring of women with diabetes. Diabetic Medicine, 22(6), 693-696.

Nold, J. L., \& Georgieff, M. K. (2004). Infants of diabetic mothers. Pediatric Clinics of North America, 51(3), 619-637.

Ou, Y., Mai, J., Zhuang, J., Liu, X., Wu, Y., Gao, X., Nie, Z., Qu, Y., Chen, J., Kielb, C., Lauper, U., \& Lin, S. (2016). Risk factors of different congenital heart defects in Guangdong, China. Pediatric Research, 79(4), 549-558.

Peng, J., Meng, Z., Zhou, S., Zhou, Y., Wu, Y., Wang, Q., Wang, J., \& Sun, K. (2019). The non-genetic paternal factors for congenital heart defects: A systematic review and meta-analysis. Clinical Cardiology, 42(7), 684-691.

Polifka, J. E., \& Friedman, J. M. (2002). Medical genetics: 1. Clinical teratology in the age of genomics. Canadian Medical Association Journal, 167(3), 265-273.

Rappazzo, K. M., Warren, J. L., Meyer, R. E., Herring, A. H., Sanders, A. P., Brownstein, N. C., \& Luben, T. J. (2016). Maternal residential exposure to agricultural pesticides and birth defects in a 2003 to 2005 North Carolina birth cohort. Birth Defects Research. Part A, Clinical and Molecular Teratology, 106(4), 240-249.

Roest, P. A., van Iperen, L., Vis, S., Wisse, L. J., Poelmann, R. E., Steegers-Theunissen, R. P., Molin, D. G., Eriksson, U. J., \& Gittenberger-De Groot, A. C. (2007) Exposure of neural crest cells to elevated glucose leads to congenital heart defects, an effect that can be prevented by N-acetylcysteine. Birth Defects Research. Part A, Clinical and Molecular Teratology, 79(3), 231-235.

Rosamond, W., Flegal, K., Friday, G., Furie, K., Go, A., Greenlund, K., Haase, N., Ho, M., Howard, V., Kissela, B., Kittner, S., Lloyd-Jones, D., McDermott, M., Meigs, J., Moy, C., Nichol, G., O’Donnell, C. J., Roger, V., Rumsfeld, J., Sorlie, P., Steinberger, J., Thom, T., Wasserthiel-Smoller, S., Hong, Y, \& American Heart Association Statistics Committee and Stroke Statistics Subcommittee (2007). Heart disease and stroke statistics - 2007 update: A report from $\$ 29$ 
American Heart Association Statistics Committee and Stroke Statistics Subcommittee. Circulation, 115(5), e69-171.

Rufer, E. S., Hacker, T. A., Flentke, G. R., Drake, V. J., Brody, M. J., Lough, J., \& Smith, S. M. (2010). Altered cardiac function and ventricular septal defect in avian embryos exposed to low-dose trichloroethylene. Toxicological Sciences, 113(2), $444-452$.

Saxena, A. (2018). Congenital heart disease in India: A status report. Indian Pediatrics, 55(12), 1075-1082.

Scanlon, K. S., Ferencz, C., Loffredo, C. A., Wilson, P. D., Correa-Villasenõr, A. Khoury, M. J., \& Willett, W. C. (1998). Preconceptional folate intake and malformations of the cardiac outflow tract. Baltimore-Washington Infant Study Group. Epidemiology, 9, 95-98.

Selevan, S. G., Kimmel, C. A., \& Mendola, P. (2000). Identifying critical windows of exposure for children's health. Environmental Health Perspectives, 108(Suppl 3), $451-455$.

Shi, Q. Y., Zhang, J. B., Mi, Y. Q., Song, Y., Ma, J., \& Zhang, Y. L. (2014). Congenital heart defects and maternal fever: Systematic review and meta-analysis. Joumal of Perinatology, 34(9), 677-682.

Shillingford, A. J., \& Weiner, S. (2001). Maternal issues affecting the fetus. Clinics in Perinatology, 28(1), 31-70.

Smitha, R., Karat, S. C., Narayanappa, D., Krishnamurthy, B., Prasanth, S. N., \& Ramachandra, B. (2006). Prevalence of congenital heart diseases in Mysore. Indian Joumal of Human Genetics, 12(1), 11-16.

Steel, Z., Marnane, C., Iranpour, C., Chey, T., Jackson, J. W., Patel, V., \& Silove, D. (2014). The global prevalence of common mental disorders: A systematic review and meta-analysis 1980-2013. International Journal of Epidemiology, 43(2), 476-493.

Su, X. J., Yuan, W., Huang, G. Y., Olsen, J., \& Li, J. (2015). Paternal age and offspring congenital heart defects: A national cohort study. PLoS One, 10(3), $\mathrm{e} 0121030$.
Tanner, J. P., Salemi, J. L., Stuart, A. L., Yu, H., Jordan, M. M., DuClos, C., Cavicchia, P., Correia, J. A., Watkins, S. M., \& Kirby, R. S. (2015). Associations between exposure to ambient benzene and $\mathrm{PM}(2.5)$ during pregnancy and the risk of selected birth defects in offspring. Environmental Research, 142, 345-353.

Tegethoff, M., Greene, N., Olsen, J., Schaffner, E., \& Meinlschmidt, G. (2011). Stress during pregnancy and offspring pediatric disease: A national cohort study. Environmental Health Perspectives, 119(11), 1647-1652.

Van der Lugt, N. M., van de Maat, J. S., van Kamp, I. L., Knoppert-van der Klein, E. A., Hovens, J. G., \& Walther, F. J. (2012). Fetal, neonatal and developmental outcomes of lithium-exposed pregnancies. Early Human Development, 88(6), 375-378.

Vrijheid, M., Dolk, H., Stone, D., Abramsky, L., Alberman, E., \& Scott, J. E. (2000) Socioeconomic inequalities in risk of congenital anomaly. Archives of Disease in Childhood, 82(5), 349-352.

Wheeler, S. M., Dotters-Katz, S., Heine, R. P., Grotegut, C. A., \& Swamy, G. K. (2015). Maternal effects of respiratory syncytial virus infection during pregnancy. Emerging Infectious Diseases, 21(11), 1951-1955.

Wren, C., Irving, C. A., Griffiths, J. A., O’Sullivan, J. J., Chaudhari, M. P., Haynes, S. R., Smith, J. H., Hamilton, J. R., \& Hasan, A. (2012). Mortality in infants with cardiovascular malformations. European Journal of Pediatrics, 171(2), 281-287.

Wren, C., Reinhardt, Z., \& Khawaja, K. (2008). Twenty-year trends in diagnosis of life-threatening neonatal cardiovascular malformations. Archives of Disease in Childhood. Fetal and Neonatal Edition, 93(1), F33-F35.

Wu, W., He, J., \& Shao, X. (2020). Incidence and mortality trend of congenital heart disease at the global, regional, and national level, 1990-2017. Medicine (Baltimore), 99(23), e20593. 